\title{
Geri dönüşüm sürecinde kusurlu yeniden üretim durumu için yeni bir envanter modeli
}

\section{A new inventory model for re-production with imperfect items in recycling process \\ Ramazan Eroğlu 1(), Erdal Aydemir ${ }^{2 *}(\mathbb{C}$}

${ }^{1}$ Süleyman Demirel Üniversitesi Sosyal Bilimler Enstitüsü İşletme Anabilim Dalı, Isparta, TÜRKIYE
${ }^{2}$ Süleyman Demirel Üniversitesi Mühendislik Fakültesi Endüstri Mühendisliği Bölümü, Isparta, TÜRKIYE
Sorumlu Yazar / Corresponding Author*: erdalaydemir@sdu.edu.tr

$\begin{array}{ll}\text { Geliş Tarihi / Received: 04.04.2020 } & \text { Araștırma Makalesi/Research Article } \\ \text { Kabul Tarihi / Accepted: 24.01.2021 } & \text { DOI:10.21205/deufmd.2021236804 }\end{array}$

Atıf șekli/How to cite: EROĞLU, R., AYDEMIR, E. (2021). Geri dönüşüm sürecinde kusurlu yeniden üretim durumu için yeni bir envanter modeli. DEUFMD. 23(68), 381-397.

\section{$\ddot{0 z}$}

Bu çalışmada, geri dönüşüm sürecinde toplanan ürünlerin yeniden üretim yoluyla geri kazanımı esnasında yeniden üretim sürecine dahil olan ürünlerin bir kısmının kusurlu olabileceği durum için yeni bir envanter modeli geliștirilmiștir. Önerilen model, bilimsel yazında yer alan Dobos ve Richter (2004) geri dönüşüm envanter modelinin kusurlu üretim durumunu ele alan özel bir halidir. Model örnek bir uygulama problemi ile desteklenerek çözümlenmiştir. Ayrıca, marjinal geri alım oranı, kullanım oranı ve geri dönüşüm iyi kalite ürün oranı değerleri için birim zamandaki toplam maliyet, geri dönüşüm ve yeniden üretim parti büyüklüğüne göre değişim sonuçları için üç faktör üç seviye olacak şekilde bir tam faktöriyel L27 deney tasarım uygulaması gerçekleştirilmiştir. Sonuçta, geri dönüşüm sürecinde yeniden üretim işlemlerinin de belirli bir oranda kusurlu olmasının etkileri gösterilmiştir. Bunun yanı sıra modelin gelecek araştırması olarak geri dönüşüm envanter modelleri için araştırmacılar ve endüstri uygulayıcıları için araştırma boşlukları ve fırsatları gösterilmiştir.

Anahtar Kelimeler: Geri dönüșüm süreci, Envanter modeli, Kusurlu üretim, Yeniden üretim

\begin{abstract}
In this study, a new inventory model has been developed for the case that some of the products involved in the re-production process may be defective during the recovery process of the products collected via the recycling process. The proposed new model is a special case of Dobos and Richter (2004) recycling inventory model in the scientific literature dealing with the defective production situation. The model is solved by supporting wih a numerical instance. In addition, a full factorial L27 test design was performed with three levels for three factors for a total cost per unit time, change in recycling and reproduction by batch size for marginal buyback rate, utilization rate and recycling good quality product ratio values. As a result, the effects of some defect of re-production processes in the recycling process have been shown with the proposed inventory model. In addition, research gaps and opportunities for researchers and industry practitioners for recycling inventory models are shown as further research of the model.
\end{abstract}

Keywords: Recycling process, Inventory model, Imperfect production, Re-production 


\section{Giriş}

\subsection{Geri Dönüşüm Süreci}

Geri dönüşüm süreci, yeniden kullanımı sağlamak için malzemelerin, bileşenlerin ve ürünlerin geri kazanılmasını ve yeniden üretilmesini (işlenmesini) de içerecek şekilde kullanılmaktadır. Başka bir deyişle geri dönüşüm, atıkların yeniden kullanılmasının dışında, atıkları toplayan bir üretim sürecinde atık malzemelerin yeniden işlenmesi olarak da tanımlanmaktadır. Geri dönüşüm ürünleri aynı ürün tipi olarak ya da farklı amaçlar için yeniden işleme tabi tutularak endüstriyel hayata kazandırılmaktadır [1].

Yeniden üretim endüstrisi ise; birçok sektörü içeren ve önemli ekonomik, çevresel ve sosyal faydalar sağlayan büyük bir sektördür. Bazı ișletmeler sattıkları ya da kiraladıkları ürünleri geri toplama ve yeniden üretim yoluna giderken, teknoloji yoğun ürünler üreten işletmeler ise, genellikle ürünlerini güncelleme yoluna gitmektedir. Benzer şekilde; bazı işletmeler kullanılmış ürünlerini geri toplayarak ürün içinden kullanılabilir bileşenlerini geri kazanırken, birtakım işletmeler ise geri toplanmış ürünlerinden malzeme geri kazanımı yapmaktadır. $\mathrm{Bu}$ açıdan bakıldığında geri dönüşüm temelinde yeniden işleme faaliyetleri:

- Geri dönüșüm yapma motivasyonu (ekonomik ve çevresel beklentiler),

- Geri kazanımı yaplacak parça tipi (malzeme geri kazanımı, doldurulabilir konteynirlar),

- Geri dönüşüm biçimi (malzeme geri kazanımı, bileșen kazanımı, tamir, yenileme ve/veya yeniden kullanım),

- Geri dönüşüm biçimi için gerekli süreçler (toplama, test/derecelendirme, de-montaj, yeniden ișleme ve dağıtım),

- Geri dönüșüm süreci ajanları (OEM ürünler, üçüncü parti işletmeler ve tüketiciler),

- Geri dönüşüm faaliyetlerinin yeri (varolan veya yeni tesisler),

şeklinde tanımlanabilir [2]. Son yıllarda, kullanılmıș ürünün yeniden üretilmesinin önemi, çevreyi korumak ve sürdürülebilir uygulamaları geliştirmek amacıyla araştırmacılar ve endüstriyel işletmeler tarafından büyük ölçüde aksiyon olarak ele alınmaktadır. Yeniden üretim, kullanılmıs envanterlerin kullanım sürelerini uzattığı için atıkların azalmasına ve doğal kaynakların korunmasını sağlamaktadır [3]. Sonuçta, atıkları girdi olarak kullanmak, diğer girdi kaynakları için karşılaşılabilecek kıtlık durumlarının ortaya çıkmasını azaltacaktır [1]. Böylece hem enerji tasarrufu sağlanabilecek hem de atıkların depolama alanlarını azaltarak çevresel sorunları en aza indirgenmiş olabilecektir [4]. Bu durum, aynı zamanda çevresel faktörlerin en aza indirilmesinin yanı sıra ekonomik açıdan da faydaları getirmektedir. Örneğin, yeniden üretim durumunda, yeniden üretilmiş bir parçanın maliyeti genellikle yeni bir parçanın maliyetinden \%30-50 oranında daha azdır ve bu nedenle geri dönüşüm için toplam üretim maliyeti ilk üretim durumunda olduğundan daha düșüktür [5]. Ayrıca, yeniden üretim sürecinin başarılı uygulamalarına çeşitli sektörlerde faaliyet gösteren Dell, General Motors, HewlettPackard (HP), IBM, Kodak ve Xerox gibi birçok söz sahibi ve alanlarında öncü işletmede rastlanılmaktadır [2]. Geri dönüșüm süreci aşamaları altı başlık altında incelenmektedir. $\mathrm{Bu}$ aşamalar toplama, ayırma, sökme, stok kontrol, değerlendirme ve yeni ürünü ekonomiye kazandırma şeklinde Şekil 1 ile gösterilmiştir.

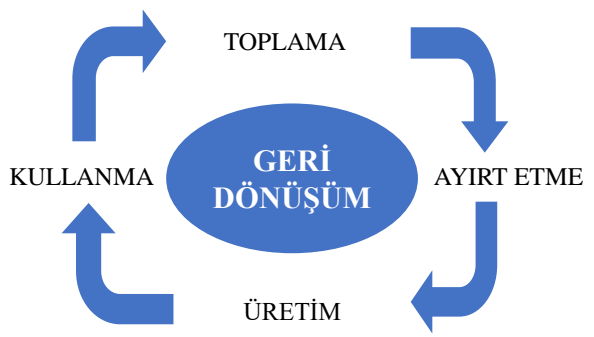

Şekil 1. Genel geri dönüşüm süreci [6]

Şekil 1'e göre geri dönüștürebilir ürünler; hangi amaçla ve yöntemle geri kazanılacak olursa olsun, atıkların ekonomik ve düzenli bir biçimde belirli bir yerde toplanmasını gerekmektedir. Bununla birlikte toplanan malzemelerin içerisinden firmanın ișine yarayan ürünlerin ve/veya yarı-mamullerin titizlik ile seçilmesi (kazanılması) sağlanmaktadır. Geri dönüșüm materyalinin durumuna göre sökme işleminde; ürünün alt montaj elamanları, bileșenleri, bütünü olușturan parçalar vs. şeklinde gruplandırılması yapılmaktadır. Bu işlemlerden sonra geri dönüșüm ürünlerini stoklama aşamasında stok kontrol maliyetlerini 
hesaplamak genellikle zordur. Stoklanan geri dönüșüm malzemeleri değerlendirme ișleminde ürün; kimyasal ve fiziksel olarak değișime uğrayarak yani değer kazandırma yoluyla yeni bir malzeme olarak ilgili pazar ekonomisine geri dönmektedir. Ekonomiye geri kazandırılması ise geri dönüșüm sürecini tamamlayan ürünün yeniden kullanıma sunulması aşamasıdır.

Öte yandan geri dönüșüm süreci sadece ticari işletmeler tarafından önemsenen bir olgu değildir. Ekonomik ve verimlilik katkılarının yanı sıra, sürdürülebilir üretim, yeşil üretim, çevre koruması vb. etkileri açısından ön plana çlkan geri dönüșüm konusu, ülkelerin stratejik planlarında geri dönüşüme teşvikler, atıkların yönetimi hususunda toplumsal farkındalığı ve sosyal sorumluluk alanlarını güçlendirici projeler ile desteklenmektedir. Ülkemizde de 2017 yılında bașlatılan "Sıfır Atık" projesi bu duruma en iyi örnek olarak verilebilir. Projede ortalama olarak yılda 31 milyon ton atık toplanarak; 42 milyon ağaç tasarrufu, 585 milyon $\mathrm{kg}$ daha az sera gazı salınımı, 69 milyon $\mathrm{m}^{3}$ daha az su kullanımı, 20 milyar $k W h$ daha düşük enerji kullanımı ve 13 milyar $T L$ katma değer beklenmektedir [7].

\subsection{Envanter Yönetimi}

Üretim sistemlerinin gelişen teknolojilere uyarlanması ve özellikle Endüstri 4.0 kapsamındaki uygulamaların yaygınlaşmaya başlamasına rağmen halen daha işletmeler açısından envanter düzeyinin takip edilmesi operasyonel düzeyde önemli bir konu olarak güncelliğini korumaktadır. Envanter yönetimi, müşteriden beklenen talebin etkin ve verimli bir şekilde karşılanabilmesi için mevcut stokların ve üretim kaynaklarının etkin bir șekilde kullanılmasına odaklanmaktadır. Envanter yönetiminin temeli, fiziksel olarak stok kontrolü uygulamasıdır. Bir çeşit sayım yapma işlemi de denilebilir. Ancak bu noktada işletmelerde üretim ve/veya sipariș yoluyla elde edilen ürünlerin; talep ve/veya üretim oranları, üretim ve/veya satınalma maliyetleri, hazırlık maliyetleri, ürünü elde bulundurma ve sonrasında ise tespit edilen bulundurmama maliyet düzeyleri nedeniyle stokta tutulan ürünlerin parasal değeri olarak envanter ifadesi kullanılmıştır.

1913 yllında Harris [8] tarafından türetilen Ekonomik Sipariş Miktarı (ESM) modeli ile bașlayan süreç Taft [9] tarafından 1918 yılında Ekonomik Üretim Miktarı (EÜM) modelinin geliştirilmesi ile bilimsel yazında sipariș ve üretim modellerinin klasik (başlangıç) modelleri olmuşlardır. Bilimsel yazında ise; klasik envanter modelleri sahip oldukları birçok varsayımı günümüzde kaybetmiș ve endüstriyel çağın gerekliliklerine göre bu klasik modellerin farklı özellikler ile genișletildiği görülmektedir [10]. Son yıllarda üretim miktarlarının çoğalması ile gerek kaynakların gerekse çevrenin korunması amacıyla yeșil üretim adı verilen yeni bir aşamaya geçilmiştir. Geliştirilen her modelde bu yeşil (çevreci) üretim yaklaşımı benimsenmekte ve önemsenmektedir. $\mathrm{Bu}$ süreçte önemli bir bașlangıç noktası olarak geri dönüşüm imkanları da özellikle tedarik zinciri yönetimi boyunca bu dönüşüm sürecinin kapalıdöngü yaklașımıyla birçok yeni model ile desteklendiği bilimsel yazında etkili bir yere sahiptir. Dolayısıyla bu çalışmanın konusu ile örtüșen kusurlu ürünler ve kalite kontrol, yeniden işleme ve geri dönüşüm envanter modellerine ait bilimsel yazın örnekleri de Tablo 1 'de verilmiş ve bu kısımda özetlenmiştir.

Tablo 1. İlgili bilimsel yazın

\begin{tabular}{ll}
\hline Konu & Bilimsel yazın örnekleri \\
\hline Kusurlu & Rosenblatt ve Lee (1986); Kim ve \\
Ürünler ve & Hong (1999); Salameh ve Jaber \\
Kalite & (2000); Chung ve Hou (2003); \\
Kontrol & Eroğlu ve Özdemir (2007); Sana \\
& (2010); Wee vd. (2013); Rezaei \\
& (2016); Pietro De Giovanni (2019) \\
Yeniden & Schrady (1967); Nahmias ve Rivera \\
İşleme & (1979); Richter (1997); Hayek ve \\
& Salameh (2001); Chan vd (2003); \\
& Dobos ve Richter (2003); Dobos ve \\
& Richter (2004); Eroğlu vd. (2008); \\
& Taleizadeh vd., (2013); Glock ve \\
& Jaber (2013); Kozlovskaya vd. \\
& (2015); Shah vd. (2018) \\
Keri- & Koh vd. (2002); Teunter (2003); \\
Dönüşüm & Fleischmann ve Kuik(2003); Dobos \\
Süreci & ve Richter (2004); Choi ve Hwang \\
& (2007); Konstantaras ve Skouri \\
& (2010); Hishamuddin vd. (2012); \\
& Giri ve Sharma (2015); \\
& Kozlovskaya vd. (2016); Marshall \\
& (2018) \\
\hline
\end{tabular}

EÜM modellerinde kusurlu ürünler bahseden önemli bir çalışma olan Rosenblatt ve Lee (1986) 
tarafından geliștirilen modelde üretim sürecinde planlama ufkunda bir ana kadar üretilen ürünlerin tamamının kusursuz olduğu ve on andan itibaren sistemin kontrol dıșına çıktığı ana kadar ki geçen sürenin üstel dağılıma uyduğu kabul edilmiştir [11]. Aynı model, Kim ve Hong (1999) tarafından modeldeki geçen sürenin genel rassal dağılıma uyduğu kabulüyle genișletilmiștir [12]. Daha sonra, Chung ve Hou (2003) tarafından ilgili modele stoksuzluğa izin verilmesi durumu eklenmiștir. Modelde üstel dağılıma uyduğu ve optimal üretim ve toplam maliyet üzerindeki etkilerini incelemek için bir duyarlılık analizi yapılmıștır [13]. Salameh ve Jaber (2000) ise; ESM modelleri için sipariși verilen bir partinin kusurlu üretim süreci sonunda gelmesi ve stoksuzluk durumu birlikte ele alan ilk çalışmayı yayınlamışlardır [14]. Bu modelin sonradan karșılama ile genișletildiği ESM modelini Eroğlu ve Özdemir (2007) yayınlamışlardır [15]. Daha sonra; Sana (2010) yaptığı çalışmada, toplam üretim miktarının belirli bir yüzdesini üretim sürecinde sisteminin kontrol dışı kalarak kusurlu hale getirdiği varsayımıyla EÜM modeli geliştirmiştir [16]. Wee vd. (2013) ise; eksik ve eleme kısıtı olan kusurlu ürünler için EÜM modeli ve çözüm prosedürü önermişlerdir [17]. ESM modellerine kusurlu ürünlerde örnekleme denetleme planları ise Rezaei (2016) tarafindan geliștirilmiștir [18]. De Giovanni (2019) kusurlu ürünlerin olumsuz etkilerini azaltmaya yönelik model önerisinde bulunmuştur. Sonuçta, toplam kalite yönetiminin ayrıca ișletmelerin mali olmayan fark yaratan değerleri üzerinden kusurlu üretim süreçlerine yönelmesi gerektiğini belirtmiştir [19].

ESM ve EÜM modellerinin yeniden ișleme süreçleri ile yapılan genişletmeleri incelendiğinde, optimal üretim miktarı ve tamir edilebilir ürün miktarına karar vermeye çalıșan ilk matematiksel model Schrady (1967) tarafından geliștirilmiștir [20]. Daha sonra bu model, sonlu ve belirli bir tamir oranına izin verecek şekilde Nahmias ve Rivera (1979) tarafından genișletilmiștir [21]. Ayrıca, Schrady (1967) modelini, bir ESM modeli olarak tamir edilebilir, tamir edilemez ve hurda/atık ürün durumu şeklinde Richter (1997) modellemiștir. Çalışmada tanımlanan değiştirme maliyeti, modelleme sürecinde tamirden üretime ve üretimden onarıma geçildiğini temsil etmektedir [22]. Hayek ve Salameh (2001) tarafından ise; stoksuzluğa izin verilmesi, kusurlu ürünlerin tamamının yeniden ișlenmesi yoluyla kusursuz hale getirilmesi ve yeniden ișleme süresinin dikkate alınması șeklinde bir EÜM modeli olarak geliștirilmiștir [23]. Üretim süreci boyunca ürünler kusursuz ve kusurlu kabul edilen ürünler, düşük kalite düzeyinde kusursuz (indirimli satıș fiyatı ile satılabilen), tamir edilebilecek kusursuz ve iskarta şeklinde üç farklı şekilde Chan vd. (2003) tarafından sınıflandırılmıștır [24]. Dobos ve Richter (2003) ve (2004) yıllarında yaptıkları çalışmalarda; önce tersine lojistik yaklaşımı ile yeniden işleme/üretim ve atık ürünleri içeren model geliştirmiş ve sonrasında aynı modele öğrenme etkisinin eklenmesi ile yeni bir EÜM modeli önermişlerdir [25, 26]. Aynı zamanda bu iki model tersine lojistik yapısı nedeniyle geri dönüşüm modeli olarak ele alınabilmektedir. Eroğlu vd. (2008) tarafından ise; stoksuzluğa izin veren ve tamir süresini içerecek şekilde iki farklı endüstriyel uygulama problemi ile desteklenerek sunulmuștur [27]. Ayrıca, kusurlu ürünler, yeniden işleme ve hurda ürünler varsayımlarının birkaçını aynı anda içeren modeller de Taleizadeh vd. (2013) [28] ile Glock ve Jaber (2013) [29] tarafından geliştirilmiştir. Tamir maliyeti, atık/hurda yok etme maliyeti ve değiştirme maliyeti için kesin çözüm Kozlovskaya vd. (2015) tarafından önerilmiștir [30]. Öte yandan yeniden işleme konusunda bir diğer çalışma ise Shah vd. (2018) tarafından yapılmıș ve kusurlu ürünlerin tamir edildikten sonra üretim hızı, çevrim süresi dikkate alınarak perakende satıș fiyatlarından maksimum kar elde edilmesi incelenmiştir [31].

Geri dönüșüm süreçlerinin envanter modeli olarak ele alındığı çalışmalar incelendiğinde; Koh vd. (2002) tarafından deterministik modellere geri dönüşüm sürecinin eklenmesi geliştirilmiş modelde; durağan talebin geri dönüștürülmüș ürünler ve yeni satın alınan ürünlerle karşllanabileceği ortak bir ESM ve EÜM modeli birlikte ele alınmaktadır [32]. Teunter (2003) ise, yeni ürünlerin üretimi, satın alınması ve iade edilen ürünlerin geri kazanımı için en uygun parti büyüklüklerini belirleyen eşitlikleri türetmiştir [33]. Envanter yönetimi sisteminde ise; Fleischmann ve Kuik (2003) tarafından yapılan çalışmada, yeniden kullanım işlevinin envanter kontrolünün sistematik analizi açısından önemi gösterilmiştir [34]. Yine de bilimsel yazında matematiksel modelleme üzerine çalışmalara genellikle daha çok rastlanılmaktadır. Choi vd. (2007) tarafından 
yapılan çalıșmada; durağan talebin geri kazanılmış ürünlerle ve yeni satın alınan ürünlerle karșllanabileceğini içeren bir envanter modeli geliştirilmiștir [35]. Benzer şekilde; Konstantaras ve Skouri (2010) ise; üretim ve yeniden imalatla talebin karşılanabildiği bir üretim-yeniden imalat envanter modelini sunmuşlardır [36]. Hishamuddin vd. (2012) tarafından ise, üretimin süresi boyunca belirli bir süre bozulan tek aşamalı bir üretim ve geri kazanım envanter sistemi için yeni bir bozulma giderme modeli sunulmaktadır [37]. Öte yandan, belirli talep ve arz kesintisi altında kalite kaynaklı ürün geri dönüş oranı ile belirsizlik ve imalat kusurları içeren bir kapalı döngü tedarik zinciri sürecinde optimum üretim politikası sunan model Giri ve Sharma (2015) tarafindan geliştirilmiştir [38]. Kozlovskaya vd. (2016) ise; geri dönüşüm sürecinde ürünleri bir tedarikçi ve birden fazla alıcıdan oluşan bir tedarik zinciri modeli olarak ele almışlardır [39]. Marshall ve Vierstra (2018) yaptığı çalışmada, diğer çalışmalardan farklı olarak iki tür geri dönüşüm ile ürünlerin kazanılması ve kazanılan ürünleri birleştirilerek yeni ürünler ortaya çlkarılmasına ilişkin modelleri tanımlamışlardır [40].

$\mathrm{Bu}$ çalıșma ile; geri dönüșüm envanter modellerinde geri dönüşüm süreçlerinin de kusurlu ürünler üretebileceği durumunun yer aldığı geliştirilen matematiksel model ve yeni araștırma alanlarının ortaya konulması ile araştırmacılara, endüstri uygulayıcılarına ve bilimsel yazına katkılar sağlandığı düşünülmektedir.

\subsection{Motivasyon}

Bu çalışmada geri dönüşüm süreci için önerilen envanter modelinde; bilimsel yazında yer alan diğer çalıșmalardan farklı olarak, geri dönüșüm için pazardan geri toplanan ürünlerin tamamının kusursuz bir şekilde geri dönüştürülemeyeceği ele alınmaktadır. Geri dönüşüm sürecinde toplanan ürünlerin belirli bir oranı için hurda/atık (servis edilemeyen, kullanım dışı) ürünlerin olabileceğini durumunu içeren yeni bir envanter modeli geliștirilmiș ve önerilen model için işletmenin optimal kar düzeyinin elde edilmesi amacl sayısal bir örnekle desteklenmektedir. Ayrica, model parametreleri olan geri alım oranı, kullanım oranı ve geri dönüșüm iyi kalite ürün oranı parametrelerinin modeli nasıl etkilediğini göstermek için bir deney tasarımı çalışması gerçekleştirilmiştir.

\section{4. Çalışmanın Organizasyonu}

Çalışmanın birinci bölümünde, geri dönüşüm süreci ve önemi ile envanter yönetimi kapsamında geliştirilen modeller bilimsel yazın örnekleri ile açıklanmıştı. Daha sonra çalışmanın bilimsel yazındaki yerinden ve özgün değerinden bahsedilmiştir. İkinci bölümünde ise; ele alınan problemin tanımı yapılmış, önerilen model ve gerekli türetilen eşitlikler verilerek detaylıca anlatılmıştır. Üçüncü bölümde önerilen model için bir sayısal analiz çalışmasına ait çözümler verilmiştir. Ayrıca elde edilen sonuçlar için incelenen parametrelerin farklı seviyelerini dikkate alan bir deney tasarımı çalışması da gerçekleştirilmiştir. Sonuç ve tartışma kısmında ise, yapılan çalışmanın özgün değeri üzerinden yaygın etkisi ele alınmış ve gelecek araştırma firsatları sunulmuştur.

\section{Materyal ve Metot}

Çalışma kapsamında önerilen envanter modeli, Dobos ve Richter (2004) modelinde ele alınan geri dönüşüm süreci dikkate alınarak geliștirilmiștir. Dobos ve Richter (2004) modelinde; geri dönüşüm süreç şemasında üretilen ürünler belli bir oranda geri alınmakta, hurda ürünler ayrılmakta ve geri kalan ürünlerin tamamının geri dönüştürüldüğü varsayılmaktadır [26]. Bu çalıșmada ise; ilgili model üzerinden geri dönüşüm sürecinde de hurda/atık (kusurlu, servis edilemeyen, kullanım dışı) ürün ortaya çıkabileceği durumu ele alınarak genişletilmiştir.

\subsection{Notasyonlar ve Varsayımlar}

Önerilen model detaylı açıklanmadan önce, modelde ve çalışma da kullanılan gerekli notasyon ve varsayımlar detaylıca sırasıyla verilmiștir. Daha sonra ise, önerilen model için modelin şematik gösterimi, zaman boyunca envanter seviyesinin değişimini gösteren grafik ve geliştirilen matematiksel model verilmiştir.

$$
\begin{array}{cl}
- \text { Notasyonlar } & \\
D & : \text { Talep oranı } \\
\beta & : \text { Yeniden üretim oranı } \\
\gamma & : \text { Geri kazanım oranı } \\
& : \text { Üretim oranı }((1 / \beta) D) \text { burada } \\
P & (\beta<1) \text { olacak şekilde } \\
& : \text { Geri alım oranı }(0 \leq \alpha \leq 1) \\
P_{g} & : \text { Üretim iyi kalite ürün oranı }
\end{array}
$$


DEÜ FMD 23(68), 381-397, 2021

\begin{tabular}{|c|c|}
\hline$P_{S}$ & : Üretim hurda ürün oranı $\left(1-P_{g}\right)$ \\
\hline$R_{g}$ & $\begin{array}{l}\text { : Geri dönüşüm sonrası iyi kalite } \\
\text { ürün oranı }\left(\left(\frac{1}{\gamma} P_{g}\right) D\right) \text { burada } \\
(\gamma<1) \text { olacak şekilde }\end{array}$ \\
\hline$R_{s}$ & $\begin{array}{l}\text { : Geri dönüșüm sonrası hurda ürün } \\
\text { oranı }\left(\left(1-\frac{1}{\gamma} P_{g}\right) D\right)\end{array}$ \\
\hline$B$ & $\begin{array}{l}\text { : Geri dönüşüm içi kullanılacak } \\
\text { ürün miktarı }(\delta . \alpha D . T)\end{array}$ \\
\hline$S_{r}$ & $\begin{array}{l}\text { : Geri dönüşüm için hazırlık } \\
\text { maliyeti }\end{array}$ \\
\hline$S_{P}$ & : Üretim için hazırlık maliyeti \\
\hline$h_{s}$ & $\begin{array}{l}\text { : Servis edilebilir ürünler için birim } \\
\text { elde bulundurma maliyeti }\end{array}$ \\
\hline$h_{n}$ & $\begin{array}{l}\text { : Servis edilemeyen ürünler için } \\
\text { birim elde bulundurma maliyeti } \\
\text { : Geri dönüsüm süreci boyunca }\end{array}$ \\
\hline$h_{w}$ & $\begin{array}{l}\text { hurda ürünlerin birim elde } \\
\text { bulundurma maliyeti }\end{array}$ \\
\hline
\end{tabular}

Karar değișkenleri

\begin{tabular}{|c|c|}
\hline$\delta$ & : Marjinal kullanım oranı \\
\hline$\alpha$ & : Marjinal geri alım oranı \\
\hline$m$ & : Geri dönüşüm parti sayısı \\
\hline$n$ & : Üretim parti sayısı \\
\hline$T$ & $\begin{array}{l}\text { : Üretim ve geri dönüşüm çevrim } \\
\text { süresi }\end{array}$ \\
\hline$T_{R}$ & : Geri dönüşüm çevrim süresi \\
\hline$T_{P}$ & : Üretim çevrim süresi \\
\hline$T_{D}$ & $\begin{array}{l}\text { : Geri dönüşüm sonrası servis } \\
\text { edilemeyen kusurlu ürünlerin } \\
\text { bertaraf edilme çevrim süresi }\end{array}$ \\
\hline$X_{R}$ & $\begin{array}{l}\text { : Geri dönüşüm parti büyüklüğü } \\
\left(D T_{R}\right)\end{array}$ \\
\hline$X_{P}$ & : Üretim parti büyüklüğ̈̈ $\left(D T_{P}\right)$ \\
\hline
\end{tabular}

- Varsayımlar

Matematiksel model kurma sürecinde, endüstriyel (gerçek hayat) model hakkında ölçülemeyen ve/veya gerçekte var olan durumların modele yansitılmasında bazı model varsayımlarına bașvurulabilmektedir. $\mathrm{Bu}$ çalışmada önerilen kusurlu üretim içeren geri dönüşüm envanter modeli ise benzer şekilde aşağıdaki varsayımlar altında geliştirilmiştir:

- $\quad$ Talep, belirleyici ve bilinendir.

- Kullanılmıș ürünler, sabit ve belirli oranda müşterilerden toplanmışlardır.
- Toplanan ürünlerin belirli bir orandaki kısmı yenisi kadar iyileştirilebilmektedir.

- Maliyet parametreleri, bilinen sabitlerdir.

- Satın alma ve geri kazanım yönlendirme süreleri, belirli ve sabittir.

- Üretimde ve süreçte kesintilere/duraksamalara izin verilmemiștir.

- Ürünleri tamir etmek, satın almaktan daha ekonomiktir.

- Geri kazanım oranı toplama oranından daha küçüktür $(\gamma>\alpha)$.

- Talep oranı, toplama oranından daha büyüktür $(D>\alpha)$.

\subsection{Matematiksel Model}

Önerilen geri dönüşüm envanter modeli temelde Dobos ve Richter (2004) [26] modelinde ele alınan geri dönüşüm süreci boyunca hurda/atık (kusurlu, servis edilemeyen, kullanım dışı) ürün ortaya çlkabileceği durumu ile genişletilmesi yoluyla kusurlu geri dönüşüm sürecinden bahseden ilk modeldir. Önerilen modele ait süreç işleyiş şeması Şekil 2'de verilmiştir.

Şekil 2'ye göre, başlangıçta fabrikada (ișletmede) üretilen ürünler, müșterilere ulaşması için piyasaya oranında sunulur. Daha sonra bu oranında sunulan ürünlerin piyasadan (pazardan) oranında geri toplandığı varsayılmaktadır. Toplanan ürünler, işletmeye ilk geldiğinde servis edilemez olarak adlandırılmaktadır. Servis edilemez tipindeki ürünler geri dönüşüm ünitesine ulaşmadan önce bir ayıklama sürecinden geçmektedirler. Geri dönüşümü mümkün olmayan ürünler atık ürün olarak nitelendirilmektedir. $\mathrm{Bu}$ işlem sonunda geri dönüşüme oranında ürün dahil edilir. Daha sona geri dönüşüm işlemi başlamaktadır. Geri dönüşüm işlemi sırasında bazı ürünlerde bozulma olabileceğini ve kullanılamaz (hurda) ürünler oluşabileceği de önerilen modelde ele alınan temel katkıyı göstermektedir. Geri dönüşüm sürecinden sonra ise; oranında geri dönüşüme giren ürün miktarının oranında iyi kalitede servis edilebilir ürün miktarı olarak çıktığı görülmektedir. Bunun da oranındaki kısmı hurda ürün olarak atılmaktadır. Bir sonraki periyotta üretim hem geri dönüşümden sağlanan ürün hem de fabrikada üretilen ürünle sağlanarak devam etmektedir. 


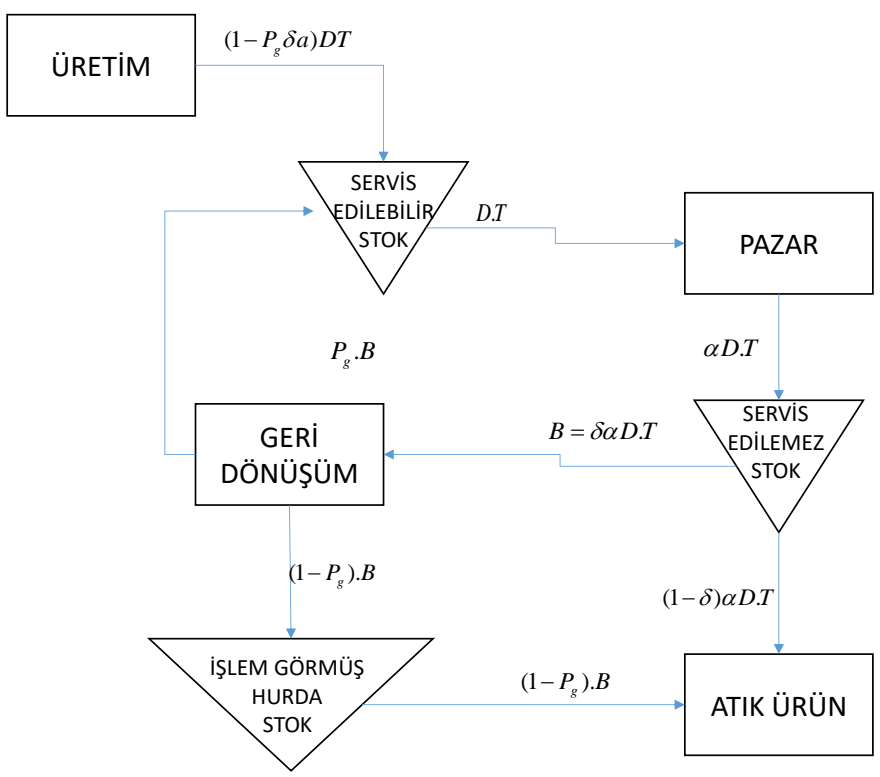

Şekil 2. Önerilen geri dönüşüm süreci için envanter akışı

Önerilen envanter modelinde; müșterilerden sabit bir oran ile toplanan kullanılmış ürünler daha sonra kullanılabilir hale getirilmektedir. Geri dönüșüm (kurtarma) süreci boyunca işleme tabi tutulan ürünlerin farklı kalite düzeyleri ortaya çıkmaktadır. Geri dönüşüm süreci sonunda ise yapılan kontroller ile kurtarılmıș ürünlerin belirli bir oranda iyi kalite (kusursuz) geri kalan kısmı ise hurda (geri dönüşümü mümkün olmayan) olarak ayrılmaktadır. Șekil 3'te ise; Dobos ve Richter (2004) [24] modeline benzer şekilde zaman boyunca geri dönüşüm envanter modelindeki envanter düzeyinin servis edilebilir ve servis edilemez ürün stoklarına göre değişimi üç geri dönüşüm periyotu ( $m=3$ ) ve iki üretim periyodu $(n=2)$ üzerinden gösterilmiştir. Önerilen geri dönüşüm envanter modelinin matematiksel modelini oluşturan tüm eșitlikler bu şekil üzerinden türetilmiştir.

Șekil 3'e göre envanter değișim düzeylerine göre matematiksel eşitlikler türetilirken, öncelikle Eş. 1'de $m$ tane geri dönüşüm süreci ve $n$ tane üretim süreci toplam çevrim süresi hesaplanmaktadır. Eş. 2 ile; geri dönüşüm sonrası servis edilemeyen kusurlu ürünlerin bertaraf edilme çevrim süresi belirlenmektedir.
Ayrıca, Eş. 3 'te geri dönüşüm çevrim süresi ile talep oranı ve geri kazanım oranı ile iyi kalite oranlarına göre geri dönüşüm süreci servis edilebilir envanter düzeyi elde edilmektedir. Benzer şekilde, Eş. 4'te ise; üretim süreci çevrim sürelerinde talep oranı ve üretim oranına bağlı olarak iyi kalitede üretim süreci servis edilebilir envanter düzeyi hesaplanmaktadır. Servis edilemeyen ürünler için başlangıç envanter düzeyi değeri Eş. 5 ile gösterilmektedir.

$$
\begin{aligned}
& T=m T_{R}+n T_{P} \\
& T_{D}=(1-\delta) T
\end{aligned}
$$

$I_{R}=T_{R} D\left(1-\frac{\gamma}{P_{g}}\right)$

$$
I_{P}=T_{P}\left(1-\frac{\beta}{P_{g}}\right) D
$$

$I_{n}=[(1-\alpha) m+\alpha(1-\gamma)] D T_{R}$ 


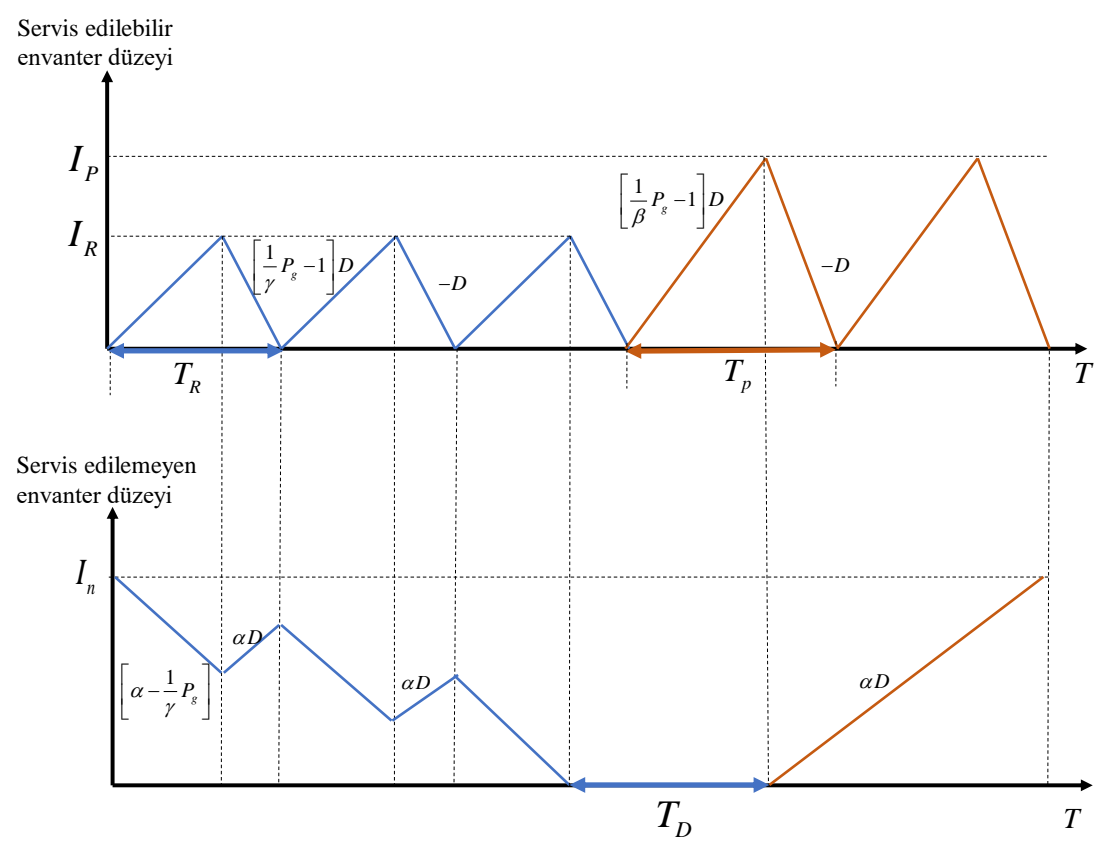

Şekil 3. Önerilen geri dönüşüm modelinin planlama ufku boyunca envanter değişimi $(m=3, n=2)$

Toplam maliyet eşitliklerinin türetilmesi sürecinde geri alım oranının ( $\alpha$ ) ve kullanım oranının $(\delta)$ pozitif olduğu ve bire eşit olmadığını varsayımı altında geri dönüşüm sürecinin yanı sıra üretim sürecinin de tanımlı olduğu kabul edilsin $(m=3 ; n=2)$. Servis edilebilir ürünler için toplam maliyet $\left(H_{R}\right)$ hesaplamasında; geri dönüșüm sürecinde birim bașına iyi kalite ve birim bașına servis edilemeyen (hurda) elde bulundurma maliyetleri dikkate alınmıştır (Eş. 6). Benzer şekilde; üretim süreci sonunda yeniden üretilen ürünler için toplam maliyet $\left(H_{P}\right)$ hesaplamasında servis edilebilir ürünler için birim elde bulundurma maliyetine göre hesaplama yapılmıștır (Eş. 7) ve Eş. 8'de ise; servis edilemeyen ürünler için toplam maliyet ( $H_{N}$ ) hesaplanmasında ise birim başına servis edilemeyen (hurda) elde bulundurma maliyetleri kullanılmıștır.

$$
\begin{aligned}
& H_{R}=\frac{1}{2 m} D T^{2} \alpha^{2} \delta^{2}\left[h_{s}\left(1-\frac{\gamma}{P_{g}}\right)+h_{n}\left(1-P_{g}\right)\right] \\
& H_{P}=\frac{1}{2} n I_{P} T_{P} h_{s}=\frac{1}{2} D T^{2} h_{s}(1-\beta)\left(1-P_{g} \alpha \delta\right)^{2} \frac{1}{n} \\
& H_{N}=\frac{1}{2} D T^{2} h_{n}(1-\gamma) \alpha^{2} \delta^{2} \frac{1}{m}+\frac{1}{2} D T^{2} h_{n} \alpha(1-\alpha) \delta^{2}
\end{aligned}
$$

Çevrim zamanı başına toplam elde bulundurma maliyeti $\left(H_{T}\right)$ hesaplamasında ise Eş. 6-8'de verilen maliyetlerin planlama ufku ( $T$ ) boyunca değeri hesaplanmıştır. Burada eşitliğin kapalı hali için bir $V$ fonksiyonu kullanılmıştır. Eş. 9'de verilen hesaplamada yer alan $V$ fonksiyonunun açık hali Eş. 10'da verilmiştir.

$$
H_{T}=\frac{H_{R}+H_{P}+H_{n}}{T}=\frac{1}{2} \operatorname{TDV}\left(m, n, \alpha, \delta, \gamma, P_{g}\right)
$$




$$
\begin{aligned}
V\left(m, n, \alpha, \delta, \gamma, P_{g}\right) & =h_{s}(1-\beta)\left(1-\alpha \delta P_{g}\right)^{2} \frac{1}{n} \\
& +h_{s}\left(1-\frac{\gamma}{P_{g}}\right) \alpha^{2} \delta^{2} \frac{1}{m}+h_{w}\left(1-P_{g}\right) \alpha^{2} \delta^{2} \frac{1}{m} \\
& +h_{n}(1-\gamma) \alpha^{2} \delta^{2} \frac{1}{m}+h_{n} \alpha(1-\alpha) \delta^{2}
\end{aligned}
$$

Toplam hazırlı maliyeti hesaplamasında ise, birim başına hazırlık maliyeti geri dönüşüm süreci $\left(S_{R}\right)$ ve yeniden üretim süreci $\left(S_{P}\right)$ olacak șekilde ayrı ayrı ele alınmalı ve bütünleșik model için süreç sayıları ile çarpılarak toplanmalıdır (Eş. 11).

$$
S_{T}(m, n)=S_{R} m+S_{P} n
$$

Birim zamanda toplam maliyet fonksiyonu $\left(T C_{U}\right.$

, Eş. 12) elde edilirken toplam hazırlık maliyeti

$$
\begin{aligned}
& T C_{U}\left(T, m, n, \alpha, \delta, \gamma, P_{g}\right)=\frac{S_{T}(m, n)}{T}+\frac{1}{2} T D V\left(m, n, \alpha, \delta, \gamma, P_{g}\right) \rightarrow e n k \\
& T^{*}\left(m, n, \alpha, \delta, \gamma, P_{g}\right)=\sqrt{\frac{2 S_{T}(m, n)}{D V\left(m, n, \alpha, \delta, \gamma, P_{g}\right)}} \\
& T C_{U}^{*}=\left(m, n, \alpha, \delta, \gamma, P_{g}\right)=\sqrt{2 D S_{T}(m, n) V\left(m, n, \alpha, \delta, \gamma, P_{g}\right)} \\
& T_{R}^{*}\left(m, n, \alpha, \delta, \gamma, P_{g}\right)=\frac{P_{g} \alpha \delta}{m} \sqrt{\frac{D V\left(m, n, \alpha, \delta, \gamma, P_{g}\right)}{2 S_{T}(m, n)}} \\
& T_{P}^{*}\left(m, n, \alpha, \delta, \gamma, P_{g}\right)=\frac{1-P_{g} \alpha \delta}{n} \sqrt{\frac{2 S_{r}(m, n)}{D V\left(m, n, \alpha, \delta, \gamma, P_{g}\right)}}
\end{aligned}
$$

Ayrıca, en uygun parti büyüklüğü değerleri geri dönüşüm süreci ( $X_{R}^{*}$, Eş. 17) ve yeniden üretim süreci ( $X_{P}^{*}$, Eş. 18) için hesaplanabilmektedir. Sonuçta, önerilen geri dönüşüm envanter modeli 
için toplam maliyeti en küçükleyen en uygun parti büyüklüğü miktarları elde edilmektedir.

$$
\begin{aligned}
& X_{R}^{*}\left(m, n, \alpha, \delta, \gamma, P_{g}\right)=\frac{P_{g} \alpha \delta}{m} \sqrt{\frac{2 D S_{T}(m, n)}{V\left(m, n, \alpha, \delta, \gamma, P_{g}\right)}} \\
& X_{P}^{*}\left(m, n, \alpha, \delta, \gamma, P_{g}\right)=\frac{1-P_{g} \alpha \delta}{n} \sqrt{\frac{2 D S_{T}(m, n)}{V\left(m, n, \alpha, \delta, \gamma, P_{g}\right)}}
\end{aligned}
$$

\section{Bulgular}

\subsection{Uygulama}

$\mathrm{Bu}$ bölümde geliștirilen geri dönüşüm modeli,

Dobos ve Richter (2004) [26] çalışmasında verilen sayısal örneğe uyarlanmıștır. Sayısal örneğe parametre değerleri Tablo 2'de verilmiștir.

\begin{tabular}{|c|c|c|c|c|}
\hline$D=1000$ & $\mathrm{~h}_{w}=20$ & $\mathrm{~m}=1$ & $\delta=\frac{2}{3}$ & $\mathrm{P}_{g}=0.95$ \\
\hline $\mathrm{h}_{s}=850$ & $\beta=\frac{2}{3}$ & $\mathrm{n}=2$ & $\mathrm{~S}_{R}=440$ & \\
\hline$h_{n}=80$ & $\gamma=\frac{2}{3}$ & $\alpha=\frac{1}{2}$ & $S_{P}=1960$ & \\
\hline
\end{tabular}

Tablo 2. Uygulama örnek verileri

Tablo 2'de verilen model değerlerine göre çevrim başına toplam envanter maliyeti değeri, Eş. 19-20 yardımıyla elde edilmektedir.

$$
\begin{aligned}
& V\left(1,2, \frac{1}{2}, \frac{2}{3}, \frac{2}{3}, 0.95\right)=111,2019 \\
& H_{T}=\frac{1}{2} \cdot T \cdot 1000.111,2019=55600,95 \times T
\end{aligned}
$$

Daha sonra, toplam hazırlık maliyeti Eş. 21 ile hesaplanmıștır. Ardından toplam maliyet fonksiyonunu en küçük yapmaya çalışan eșitlik çevrim süresinin bir fonksiyonu olarak Eş. 22 ile gösterilmiștir. Sonrasında ise örnek problem için; en uygun çevrim süresi Eş. 23'te, geri dönüşüm ve yeniden üretim süreçleri için sırasıyla Eş. 24 ve 25 'teki gibi hesaplanmaktadır. Geri dönüşüm çevrim süresi sonrasında ortaya çıkan kusurlu ürünlerin (hurda) bertaraf edilmesi için çevrim süresi Eş 26 ile hesaplanmaktadır. 
$T\left(1,2, \frac{1}{2}, \frac{2}{3}, \frac{2}{3}, 0.95\right)=0.28$ y1l $\cong 102$ gün

$T_{R}=0.1194$ y1l $\cong 44$ gün

$T_{P}=0.0803 \mathrm{y} 1 \mathrm{l} \cong 29$ gün

$$
T_{D}=0.0924 \text { y1l } \cong 34 \text { gün }
$$

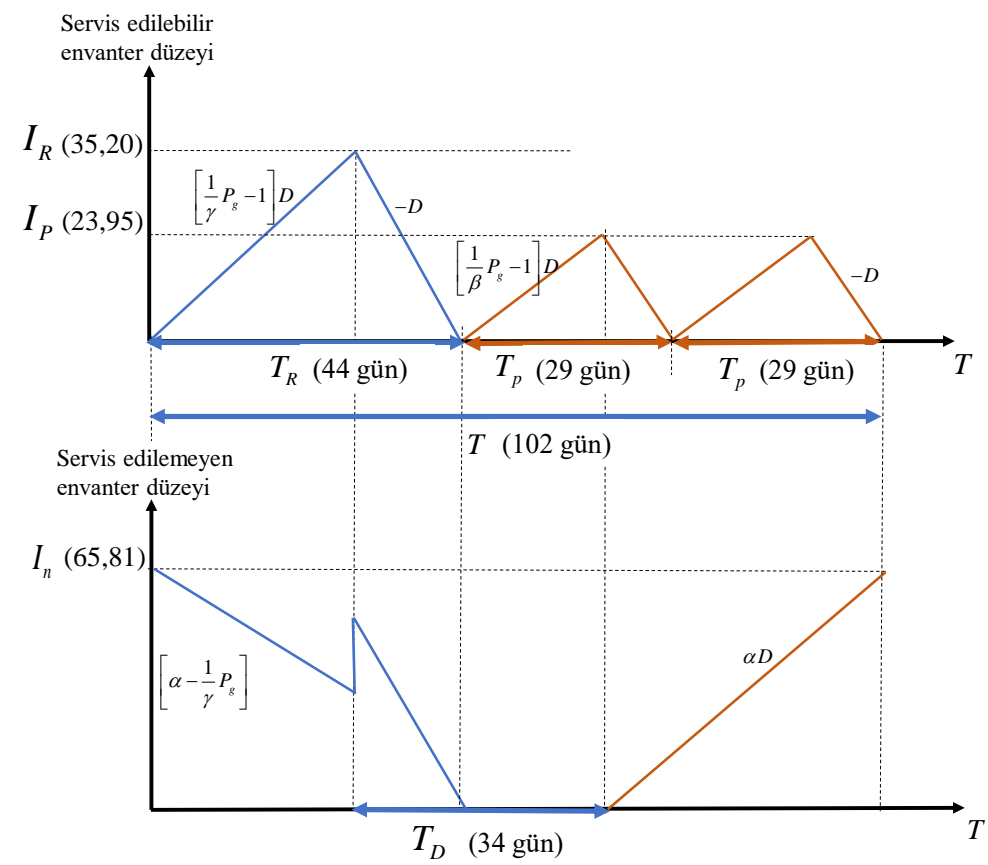

Şekil 4. Uygulama problemi için planlama ufku boyunca envanter değişimi ( $m=1 ; n=2$ )

Geri dönüşüm süreci için çevrim süresi 44 gün ve üretim süreci için çevrim süresi ise 29 gün olarak belirlenmektedir. Örnek problem, bir geri dönüșüm süreci ve iki üretim sürecinden oluşmaktadır ( $m=1, n=2$ ). Dolayısıyla sistem için çevrim süresi

$T=m T_{R}+n T_{P}=0.28$ y1l $\cong 102$ gün olarak hesaplanmaktadır (Eş. 23). 
Cevrim süresi hesaplandıktan sonra Eș. 22'de verilen çevrim zamanın toplam maliyet fonksiyonunun bu örnek problem için en küçük olduğu en uygun toplam maliyet değeri Eș. 27'de verildiği gibi elde edilebilmektedir. Daha sonra geri dönüşüm ve üretim parti büyüklüğü düzeyleri Eș. 28'de verilmektedir. Son olarak da geri dönüşüm, üretim ve servis edilemeyen stok düzeyleri için en büyük envanter düzeyleri sırasıyla Eș. 29'da olduğu gibi hesaplanmaktadır. Örnek problem için zaman boyunca envanter düzeyinin değişimini gösteren grafik Şekil 4 olarak verilmektedir.

$$
\begin{aligned}
& T C U^{*}\left(1,2, \frac{1}{2}, \frac{2}{3}, \frac{2}{3}, 0.95\right)=\sqrt{2 \times 1000 \times 4360 \times 11,2019}=31139,70 \\
& X_{R}=119,42 \text { ve } X_{P}=80,30 \\
& I_{R}=35,20 ; I_{P}=23,95 \text { ve } I_{n}=65,81
\end{aligned}
$$

\section{2. Önerilen Model İçin Deney Tasarımı ve Analizi}

$\mathrm{Bu}$ bölümde önerilen model için marjinal geri alım oranı $(\alpha)$, kullanım oranı $(\delta)$ ve geri dönüşüm iyi kalite ürün oranı $\left(P_{g}\right)$ değerleri için birim zamandaki toplam maliyet açısından bir tam faktöriyel deney tasarımı yapılmıștır. Deney tasarımı faktörleri ve seviyelerine ait bilgiler Tablo 3'te verilmiştir.

Tablo 3. Deney tasarımı için verilen seviyeler

\begin{tabular}{lccc}
\hline & $\begin{array}{c}\text { Seviye } \\
\text { I }\end{array}$ & $\begin{array}{c}\text { Seviye } \\
\text { II }\end{array}$ & $\begin{array}{c}\text { Seviye } \\
\text { III }\end{array}$ \\
\hline $\begin{array}{l}\text { Geri alım oranı } \\
(\alpha)\end{array}$ & 0,25 & 0,50 & 0,67 \\
$\begin{array}{l}\text { Kullanım oranı } \\
(\delta)\end{array}$ & 0,25 & 0,50 & 0,67 \\
$\begin{array}{l}\text { Geri dönüşüm } \\
\text { iyi kalite ürün } \\
\text { oranı }\left(P_{g}\right)\end{array}$ & 0,95 & 0,97 & 0,99 \\
\hline
\end{tabular}

3 faktör 3 seviye olacak şekilde tasarlanan tam faktöriyel deney tasarımı modelinde L27 deney tasarımı modeli kurulmuştur. Bu göre L27 tasarımı ile elde edilen birim zamanda toplam maliyet, geri dönüşüm ve yeniden üretim parti büyüklüğüne göre değişim sonuçları hesaplanmış ve Tablo 4'te verilmiştir.

Örnek uygulama problemi için geliştirilen L27 deney tasarımı modeline göre, geri alım oranı $\alpha=0,67$, kullanım oranı $\delta=0,50$ ve geri dönüşüm süreci iyi kalite ürün oranı $P_{g}=0,97$ için birim zamanda toplam maliyet 29804,28 değeri ile en küçük değerine ulaşmaktadır. Bu en küçük maliyet düzeyinde geri dönüşüm parti büyüklüğü $X_{R}=95,07$ ve Yeniden Üretim Parti Büyüklüğ̈ $\quad X_{R}=98,75 \quad$ olarak gerçekleşmektedir. L27 tam faktöriyel deney tasarım sonuçlarına göre elde edilen varyans analizi tablosu Tablo 5 olarak verilmiştir. 
DEÜ FMD 23(68), 381-397, 2021

Tablo 4. Deney tasarımı (L27) ve sonuçları

\begin{tabular}{|c|c|c|c|c|c|c|}
\hline $\begin{array}{c}\text { Deney } \\
\text { no }\end{array}$ & $\begin{array}{l}\text { Geri } \\
\text { alım } \\
\text { oranı } \\
(\alpha)\end{array}$ & $\begin{array}{c}\text { Kullanım } \\
\text { oranı } \\
(\delta)\end{array}$ & $\begin{array}{c}\text { Geri } \\
\text { Dönüşüm } \\
\text { İyi kalite } \\
\text { ürün oranı } \\
\left(P_{g}\right)\end{array}$ & $\begin{array}{r}\text { Birim } \\
\text { Zamanda } \\
\text { Toplam } \\
\text { Maliyet } \\
(T C U)\end{array}$ & $\begin{array}{r}\text { Geri } \\
\text { Dönüşüm } \\
\text { Parti } \\
\text { Büyüklüğü } \\
\left(X_{R}\right)\end{array}$ & $\begin{array}{r}\text { Yeniden } \\
\text { Üretim Parti } \\
\text { Büyüklüğü } \\
\left(X_{P}\right)\end{array}$ \\
\hline 1 & 0,25 & 0,25 & 0,95 & 33327,84 & 15,54 & 123,05 \\
\hline 2 & 0,25 & 0,25 & 0,97 & 33290,35 & 15,88 & 123,03 \\
\hline 3 & 0,25 & 0,25 & 0,99 & 33252,62 & 16,23 & 123,00 \\
\hline 4 & 0,25 & 0,50 & 0,95 & 32099,41 & 32,26 & 119,70 \\
\hline 5 & 0,25 & 0,50 & 0,97 & 32039,94 & 33,00 & 119,58 \\
\hline 6 & 0,25 & 0,50 & 0,99 & 31979,54 & 33,74 & 119,47 \\
\hline 7 & 0,25 & 0,67 & 0,95 & 31638,17 & 43,86 & 115,88 \\
\hline 8 & 0,25 & 0,67 & 0,97 & 31574,34 & 44,87 & 115,65 \\
\hline 9 & 0,25 & 0,67 & 0,99 & 31508,90 & 45,89 & 115,43 \\
\hline 10 & 0,50 & 0,25 & 0,95 & 31758,02 & 32,61 & 120,99 \\
\hline 11 & 0,50 & 0,25 & 0,97 & 31697,91 & 33,36 & 120,87 \\
\hline 12 & 0,50 & 0,25 & 0,99 & 31636,86 & 34,11 & 120,76 \\
\hline 13 & 0,50 & 0,50 & 0,95 & 30250,14 & 68,46 & 109,90 \\
\hline 14 & 0,50 & 0,50 & 0,97 & 30202,11 & 70,01 & 109,35 \\
\hline 15 & 0,50 & 0,50 & 0,99 & 30150,53 & 71,58 & 108,82 \\
\hline 16 & 0,50 & 0,67 & 0,95 & 30456,67 & 91,12 & 97,60 \\
\hline 17 & 0,50 & 0,67 & 0,97 & 30463,48 & 93,02 & 96,61 \\
\hline 18 & 0,50 & 0,67 & 0,99 & 30464,11 & 94,93 & 95,65 \\
\hline 19 & 0,67 & 0,25 & 0,95 & 30852,84 & 44,97 & 118,83 \\
\hline 20 & 0,67 & 0,25 & 0,97 & 30787,38 & 46,02 & 118,61 \\
\hline 21 & 0,67 & 0,25 & 0,99 & 30720,26 & 47,07 & 118,39 \\
\hline 22 & 0,67 & 0,50 & 0,95 & 29797,33 & 93,13 & 99,75 \\
\hline 23 & 0,67 & 0,50 & 0,97 & 29804,28 & 95,07 & 98,75 \\
\hline 24 & 0,67 & 0,50 & 0,99 & 29804,93 & 97,03 & 97,77 \\
\hline 25 & 0,67 & 0,67 & 0,95 & 31139,70 & 119,42 & 80,30 \\
\hline 26 & 0,67 & 0,67 & 0,97 & 31272,46 & 121,42 & 78,71 \\
\hline 27 & 0,67 & 0,67 & 0,99 & 31393,92 & 123,44 & 77,16 \\
\hline
\end{tabular}


DEÜ FMD 23(68), 381-397, 2021

Tablo 5. Deney tasarımı (L27) için varyans analizi

\begin{tabular}{lrrrrr}
\hline & $\begin{array}{r}\text { Serbestlik } \\
\text { Derecesi }\end{array}$ & $\begin{array}{r}\text { Kareler } \\
\text { Toplamı }\end{array}$ & $\begin{array}{r}\text { Kareler } \\
\text { Ortalaması }\end{array}$ & $\begin{array}{r}\text { F- } \\
\text { Değeri }\end{array}$ & $\begin{array}{r}\text { P- } \\
\text { Değerim Kaynağı }\end{array}$ \\
\hline Model & 6 & 25683661 & 4280610 & 48,72 & 0,000 \\
Geri alım oranı $(\alpha)$ & 2 & 15453363 & 7726682 & 87,94 & 0,000 \\
Kullanım oranı $(\delta)$ & 2 & 7207615 & 3603807 & 41,01 & 0,000 \\
Geri dönüşüm iyi kalite ürün & 2 & 3022683 & 1511341 & 17,20 & 0,000 \\
oranı $\left(P_{g}\right)$ & & & & & \\
Hata & 20 & 1757329 & 87866 & & \\
Toplam & 26 & 27440990 & & & \\
\hline
\end{tabular}

Tablo 5'e göre geri dönüșüm envanter modeli geliştirilmesinde birim zamandaki toplam maliyetin enküçük olabilmesi için en etkili değişim kaynağının kullanım oranı $(\delta)$ değerinin olduğu ve daha sonra ise; marjinal geri alım oranı ( $\alpha$ ) geri dönüşüm materyalinin üretim sürecine dahil edildikten sonraki kusursuzluk seviyesini temsil eden geri dönüşüm iyi kalite ürün oranı $\left(P_{g}\right)$ değerlerinin önemli bir etki seviyesine sahip olduğu söylenebilmektedir. L27 modelleri için birim zamanda toplam maliyet seviyelerindeki değișim Şekil 5 olarak ve geri dönüşüm ile yeniden üretim parti büyüklüğü seviyelerindeki değişim ise Şekil 6 olarak verilmiştir.

\section{Tartışma ve Sonuç}

Küreselleșen dünyada artan nüfus ve dolayısıyla tüketim toplumunun da hızla çoğalmasıyla birlikte geri dönüșüm sektörü, iş dünyası ve çevre için giderek daha fazla önem kazanmıştır. Dünyamızda doğal kaynaklar sınırlı olmakla birlikte, bilindiği üzere fosil kaynaklar da gün geçtikçe azalmaktadır. Geri dönüşüm, atıkların önlenmesi ve tekrar dünyaya kazandırılması ve dünyadaki doğal kaynakların verimli kullanılması için geliştirilmiş en etkili yöntemdir. Bunun yanı sıra ekonomik firsatlar ortaya koymakla birlikte kaynak verimliliğine de katkı sağlamaktadır. Bu noktada, ülkelerin stratejik planlarında da geri dönüşüme teşvikler, atıkların yönetimi hususunda toplumsal farkındalığ güçlendirici projeler görülmektedir.
Son yıllarda üretim miktarlarının çoğalması ile gerek kaynakların gerekse çevrenin korunması amacıyla yeşil üretim adı verilen yeni bir aşamaya geçilmiştir. Yapılan her işte ve geliştirilen her modelde bu yeşil (çevreci) üretim yaklaşımı benimsenmekte ve önemsenmektedir. $\mathrm{Bu}$ süreçte önemli bir başlangıç noktası olarak geri dönüșüm imkanları da özellikle tedarik zinciri yönetimi boyunca bu dönüşüm sürecinin kapalı-döngü yaklaşımıyla birçok yeni model ile desteklendiği bilimsel yazında etkili bir yere sahiptir.

Daha önceki çalışmalarda geri dönüșüm süreci sonunda kusursuz bir șekilde servis edilebilir ürünler elde edildiği varsayılmaktadır. $\mathrm{Bu}$ çalışmada ise; pazardan toplanan geri dönüştürülebilir ürünlerin geri dönüşüm süreci sonrasında iyi kalite ürünün yanı sıra belirli bir oranda ise kusurlu/servis edilemeyen/hurda ürün de üretebileceği durumu ele almaktadır. Geri dönüşüm süreci de kusurlu ürünler üretilebilmektedir. $\mathrm{Bu}$ durum sayısal bir uygulama örneği ile desteklenmektedir. Ayrıca, marjinal geri alım oranı, kullanım oranı ve geri dönüșen iyi kalite ürün oranı üzerindeki değişimlerin birim zamandaki toplam maliyet, geri dönüşüm ve yeniden üretim parti büyüklüğüne göre etkilerini göstermek için 3 faktör 3 seviye tam faktöriyel deney tasarımı modeli (L27) olarak önerilmiş ve sonuçları tartışılmıştır. 


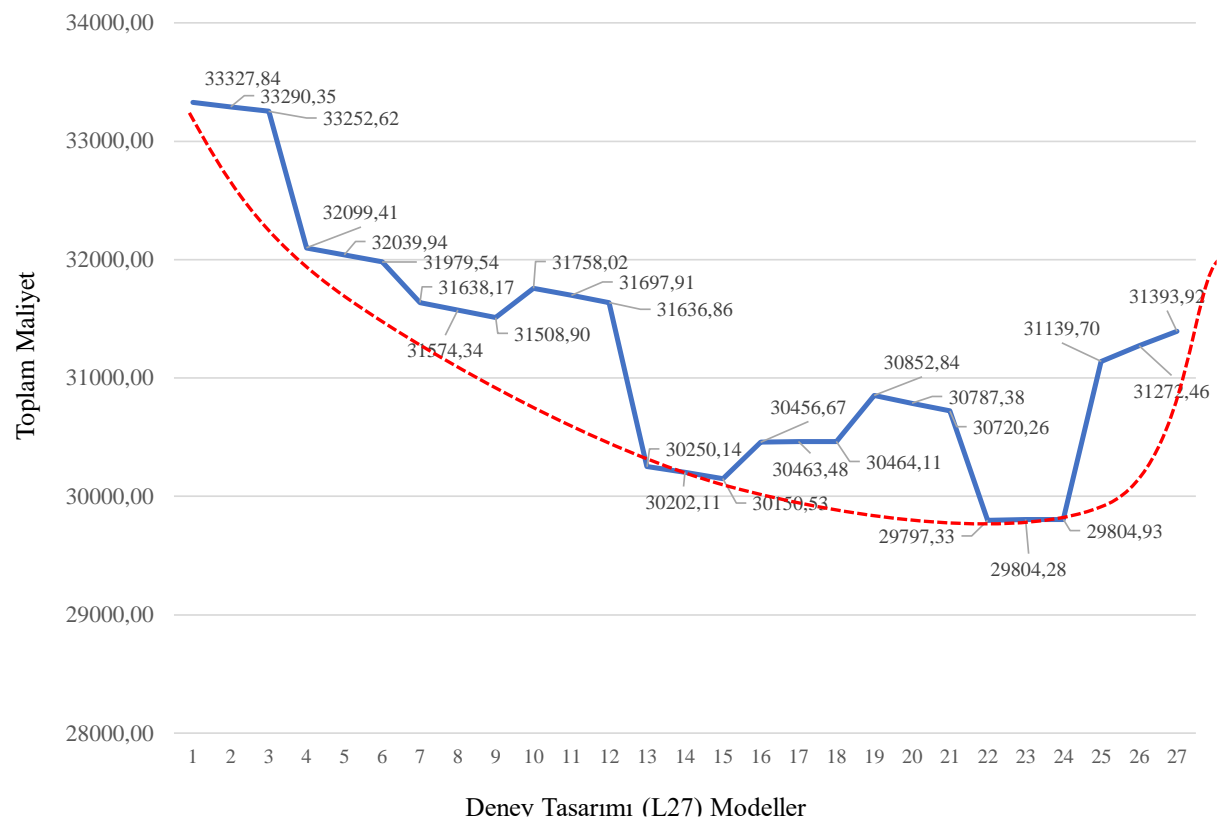

Şekil 5. L27 modelleri için birim zamanda toplam maliyet seviyeleri

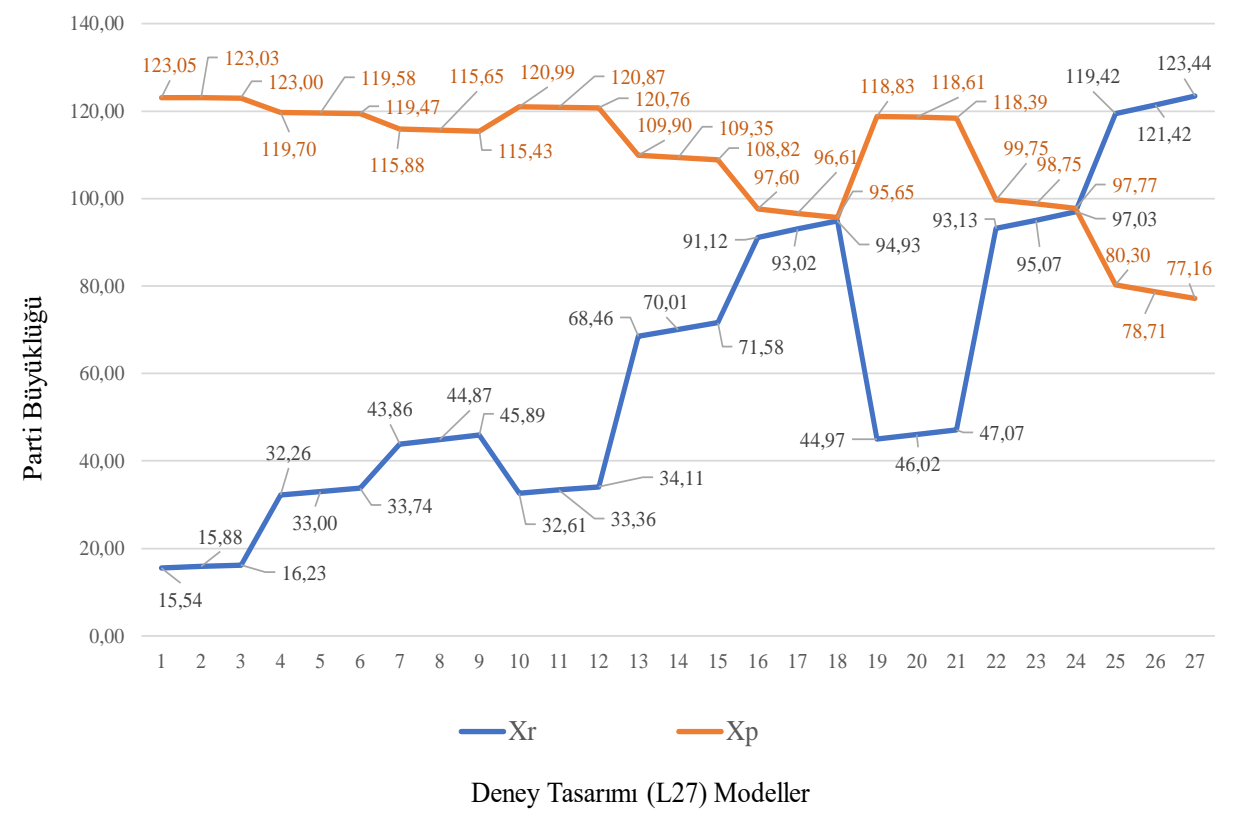

Şekil 6. L27 modelleri için geri dönüşüm ve yeniden üretim parti büyüklügü seviyeleri 
Sonuçta, geri dönüșüm sürecinde envanter yönetimi açısından geri dönüșümü sağlanmıș ve kullanıma sunulacak bir ürün için birim zamandaki toplam maliyeti etkileyen en önemli kaynağın geri alım sonrası üretime gönderilebilecek miktar olan kullanım oranı değerinin olduğu görülmektedir. İșletmeler geri dönüşüm sürecinde ilgilendikleri ürünü geri topladıktan sonra toplanan miktarın

\section{Kaynakça}

[1] G. Lafforgue and L. Rouge, "A dynamic model of recycling with endogenous technological breakthrough," Resource and Energy Economics, vol. 57, pp. 101-118, 2019.

[2] E. Akçalı and S. Cetinkaya, "Quantitative models for inventory and production planning in closed-loop supply chains," International Journal of Production Research, vol. 49, no. 8, pp. 2373-2407, 2011.

[3] M. Y. Jaber and A. M. A. El Saadany, "The production, remanufacture and waste disposal model with lost sales," International Journal of Production Economics, vol. 120, no. 1, pp. 115-124, 2009.

[4] B. K. Mawandiya, J. K. Jha and J. Thakkar, "Production-inventory model for two-echelon closed-loop supply chain with finite manufacturing and remanufacturing rates," International Journal of Systems Science: Operations \& Logistics, vol. 4, no. 3 pp. 199-218, 2017.

[5] B. C. Giri and S. Sharma, "Optimal production policy for a closed-loop hybrid system with uncertain demand and return under supply disruption," Journal of Cleaner Production, vol. 112, pp. 20152028, 2016.

[6] I. Sonmez, "Geri Dönüșüm Ne OlmalıDeğerlendirme (In turkish)," Recycling Dergisi, vol. 88, pp. 58-60, 2015.

[7] "What is zero-waste?," [Online]. Available: http://zerowaste.gov.tr/en/zero-waste/what-iszero-waste. [Accessed 2711 2018].

[8] H. F.W., "How Many Parts to Make at Once, Factory,," The Magazine of Management, vol. 10, no. 2, pp. 135152, 1913.

[9] T. E. W., "The Most Economical Production Lot," The Iron Age, vol. 101, pp. 1410-1412, 1918.

[10] A. E., "Inventory Management and Extensions: A Review of Economic Production Quantity Models," Anadolu University Journal of Social Sciences, vol. 15, no. 3, pp. 97-112, 2015.

[11] M. Rosenblatt and H. Lee, "Economic production cycles with imperfect production processes," IIE Transactions, vol. 18, no. 1, pp. 48-55, 1986.

[12] C. H. Kim and Y. Hong, "An Optimal Production Run Length in Deteriorating Production Processes," International Journal of Production Economics, vol. 58, pp. 183-189, 1999. kullanılabilir yüzdesini ve iyi kalite ürün getiri yüzdesini artırmaya yönelik operasyonları tasarlamak ve iyileştirmeye odaklanmalıdırlar. $\mathrm{Bu}$ sayede, birim zamandaki birim bașına geri dönüşüm maliyetlerinin azalması ve karlılık seviyelerinin yükselmesi beklenebilir. Dolayısıyla geri dönüşüm sürecindeki işletmelerin rekabet güçlerinin artacağı söylenebilir.

[13] K. J. Chung and K. L. Hou, "An optimal production run time with imperfect production processes and allowable shortages," Computers and Operations Research, vol. 30, pp. 483-490, 2003.

[14] M. K. Salameh and M. Y. Jaber, "Economic Production Quantity Model For Itemswith Imperfect Quality," International Journal of Production Economics, vol. 64, pp. 59-64, 2000.

[15] A. Eroglu and G. Ozdemir, "An economic order quantity model with defective items and shortages," International Journal of Production Economics, vol. 106, no. 2, pp. 544-549, 2007.

[16] S. S. Sana, "An Economic Production Lot Size Model in An Imperfect Production System," European Journal of Operational Research, vol. 201, pp. 158170, 2010.

[17] W. H.-M., W.-T. Wang and P.-C. Yang, "A Production Quantity Model For Imperfect Items With Shortage And Screening Constraint," International Journal of Production Research, vol. 51, no. 6, pp. 1869-1884, 2013.

[18] J. Rezaei, "Economic order quantity and sampling inspection plans for imperfect items," Computers \& Industrial Engineering, vol. 96, pp. 1-7, 2016.

[19] P. De Giovanni, "An optimal control model with defective products and goodwill damages," Annals of Operations Research, pp. 1-12, 2019.

[20] D. Schrady, "A Deterministic Inventory Model for Repairable Items," Naval Research Logistics, vol. 14, no. 3, pp. 391-398, 1967.

[21] S. Nahmias and H. Riviera, "A deterministic model for a repairable item inventory system with a finite repair rate," International Journal of Production Research, vol. 17, no. 3, pp. 215-221, 1979.

[22] K. Richter, "Pure and Mixed Strategies for The EOQ Repair and Waste Disposal Problem," OR Spectrum, vol. 19, no. 2, pp. 123-129, 1997.

[23] P. A. Hayek and M. K. Salameh, "Production Lot Sizing with the Reworking of Imperfect Quality Items Produced," Production Planning and Control, vol. 12 , no. 6, pp. 584-590, 2001.

[24] W. M. Chan, R. N. Ibrahim and P. B. Lochert, "A new EPQ model: integrating lower pricing, rework and reject situations," Production Planning and Control, vol. 14, no. 7, pp. 588-595, 2003.

[25] I. Dobos and K. Richter, "A Production /Recycling Model With Stationary Demand And Return Rates," 


\section{DEÜ FMD 23(68), 381-397, 2021}

Central European Journal of Operations Research, vol. 11, no. 1, pp. 35-46, 2003.

[26] I. Dobos and K. Richter, "An extended production/recycling model with stationary demand and return rates," International Journal of Production Economics, vol. 90, no. 3, pp. 311-323, 2004.

[27] A. Eroğlu, A. Sütçü and H. Sulak, "An Economic Production Quantity Model with Random Defective Rate In Imperfect Production Processes," Journal of the Faculty of Engineering and Architecture of Gazi University, vol. 23, no. 4, pp. 923-929, 2008.

[28] A. A. Taleizadeh, L. E. Cardenas-Barron and B. Mohammadi, "A Deterministic Multi Product Single Machine EPQ Model with Backordering, Scraped Products, Rework and Interruption in Manufacturing Process," International Journal of Production Economics, vol. 150, pp. 9-27, 2013.

[29] G. C. H. and M. Y. Jaber, "An Economic Production Quantity (EPQ) Model for a Customer-Domi-nated Supply Chain with Defective Items, Reworking and Scrap," International Journal of Services and Operations Management, vol. 14, no. 2, pp. 236-251, 2013.

[30] N. Kozlovskaya, N. Pakhomova and K. Richter, "Complete solution of the extended EOQ repair and waste disposal model with switching costs (No. 376)," European University Viadrina , Frankfurt (Oder), 2015.

[31] N. H. Shah, D. G. Patel and D. B. Shah, "EPQ model for returned/reworked inventories during imperfect production process under price-sensitive stockdependent demand," Operational Research, vol. 18, no. 2, pp. 343-359, 2018.

[32] S. G. Koh, H. Hwang, K. I. Sohn and C. S. Ko, "An optimal ordering and recovery policy for reusable items. , 43(1-2), 59-73.," Computers \& Industrial Engineering, vol. 43, no. 1-2, pp. 59-73, 2002.

[33] R. Teunter, "Lot-sizing for inventory systems with product recovery," Econometric Institute Report, vol. 28, pp. 1-16, 2003.

[34] M. Fleischmann and R. Kuik, "On optimal inventory control with independent stochastic item returns," European Journal of Operational Research, vol. 151, no. 1 , pp. 25-37, 2003.

[35] D. W. Choi, H. Hwang and S. Koh, "A Generalized Ordering and Recovery Policy for Reusable Items," European Journal of Operational Research, vol. 182, p. 764-774, 2007.

[36] I. Konstantaras and K. Skouri, "Lot Sizing for a Single Product Recovery System with Variable Setup Numbers," European Journal of Operational Research, vol. 203, pp. 326-335, 2010.

[37] H. Hishamuddin, R. A. Sarker and D. Essam, "A disruption recovery model for a single stage production-inventory system," European Journal of Operational Research, vol. 222, no. 3, pp. 464-473, 2012.

[38] B. C. Giri and S. Sharma, "Optimizing a closed-loop supply chain with manufacturing defects and quality dependent return rate," Journal of Manufacturing Systems, vol. 35, pp. 92-111, 2015.

[39] N. Kozlovskaya, N. Pakhomova and K. Richter, "A general production and recovery EOQ model with stationary demand and return rates (No. 378) Discussion Paper.," European University Viadrina, Frankfurt (Oder), 2016.

[40] S. E. Marshall and T. W. \& Archibald, " Lot-sizing for a product recovery system with quality-dependent recovery channels," Computers \& Industrial Engineering, 123, 134-147., vol. 123, pp. 134-147, 2018. 